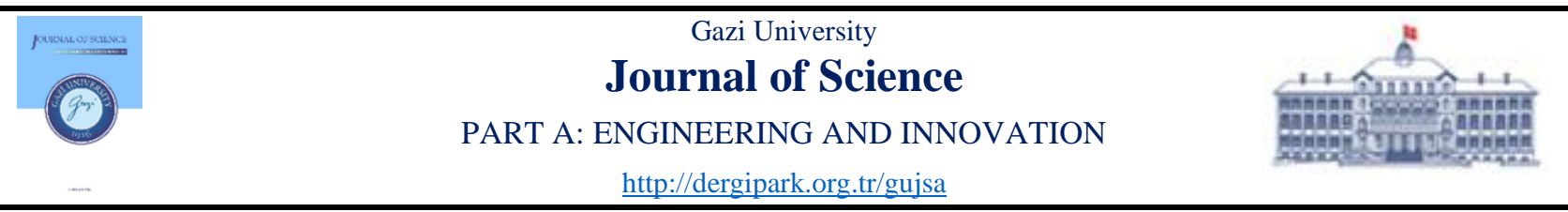

\title{
Effect of Wood-Based Panels and Varnish Types on VOC Emissions in Furniture Production
}

\author{
Hamza ÇINAR $^{1(D)}$, Kemal YILDIRIM ${ }^{*}$ (D) Mustafa HAMARAT $^{2}$ (iD \\ ${ }^{I}$ Department of Wood Products Industrial Engineering, Faculty of Technology, Gazi University, Ankara / Turkey \\ ${ }^{2}$ Ankara Metropolitan Municipality, Ankara / Turkey
}

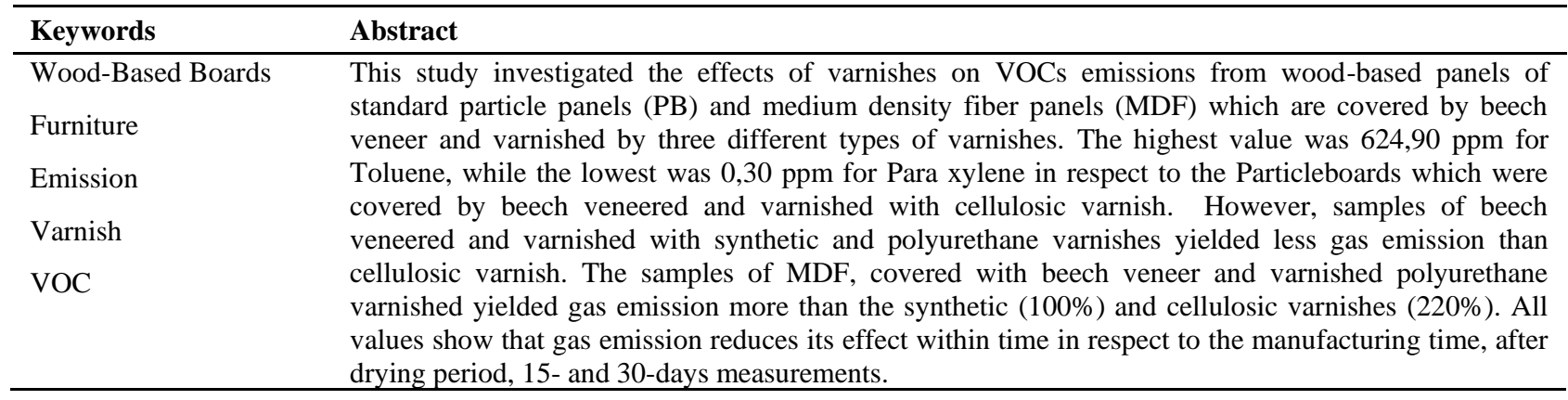

\begin{tabular}{lcc}
\hline Cite & \\
\hline \multicolumn{2}{l}{ Çınar, H., Yıldırım, K., \& Hamarat, M. (2021). Effect of Wood-Based Panels and Varnish Types on VOC Emissions in Furniture } \\
Production. GU J Sci, Part A, 8(4), 424-434. & \\
\hline Author ID (ORCID Number) & Article Process \\
\hline H. Çınar, 0000-0003-2607-852X & Submission Date & 21.10 .2021 \\
K. Yıldırım, 0000-0001-5447-1201 & Revision Date & 03.11 .2021 \\
M. Hamarat, 0000-0003-0699-191X & Accepted Date & 16.11 .2021 \\
& Published Date & 25.11 .2021 \\
\hline
\end{tabular}

\section{INTRODUCTION}

Air quality is very significant in terms of having healthy life in all aspects of lives and eco design becomes more important day by day. For example, 5 million liters of air as known of oxygen and nitrogen and are inspired by human beings in every year. On the other hand, almost fifty thousand liters of other gases (argon, carbon-dioxide i.e.) are dangerously presented into human body each year with impressive effects on the health issues regarding to the composition. Particularly in doors; offices, houses, hospitals, schools, and so on people mostly spend their time and a particular attention have been paid to the air quality of indoors (Bulian \& Fragassa, 2016).

Nowadays, many non-environmentally friendly and polluting building materials can be used in indoor architectural spaces, sometimes knowingly or unknowingly. A number of studies has been carried out on furniture and interiors livable (Subaş1 et al., 2017; Hidayetoglu \& Müezzinoglu, 2018; Yıldırım et al., 2020; 2021). However, there are few studies on the effect of volatile organic compounds (VOCs) emitted from furniture to the environment. All these pollutants emitted from furniture and equipment elements might have a negative impression on air quality, health issues of people and indoor-outdoor environments (Kephalopoulos et al., 2012). The emission of VOCs for furniture and indoors, coated with paints, varnishes, waxes, and solvents, are discussed by the authors of Missia et al. (2010), Bartzis et al. (2015), Cacho et al. (2013), Nandan et al. (2020) and Ulker et al. (2021). In addition to that, alongside with other sources; other household chemicals, cleaning agents and heating furnaces, cooking appliances and candles also contribute to air concentration of VOCs in living areas. In the last thirty years, the topic of sick building syndrome 
(SBS) becomes to the attention concerned with VOC concentrations and seriously suspected to be adjuvant factors for asthma, allergy and various symptoms (Andersson et al., 1997; Fechter et al., 2006).

Studies show that people working in the construction industry and in environments where furniture and other wood products are manufactured, repaired or restored are frequently exposed to hazardous chemicals (Cinar \& Erdogdu, 2018). In recent years, from indoor building materials, a significant approach here were raised with the exposure to VOCs. European Union (EU) Directive No 320 of 29 May 2002 puts limits on the discharge of VOCs from industrial materials, and subsequently, furniture producers have been forced to move toward alternative coating methods for wood and wood-based materials that use fewer volatile organic solvents (Akkuş et al., 2021). Even though the emissions from indoor materials decrease over time (Cinar, 2005; 2018; Brockmann et al., 1998; Benotto et al., 2009; Yu \& Kim, 2012; Cinar \& Erdogdu, 2018; Cinar et al., 2018), many building materials are repeatedly and periodically being used as interior architectural coatings, remodeling and renovation so on.

Related to the furniture industry regarding ecological concerns, there is a significant tendency for ecological production. The stricter regulations, Kyoto protocol and Paris Climate Changes Agreement and public pressures have accelerated the manufacturers how they do the business. Another significant push was conscious consumers who were aware of the raising need for more ecofriendly products. These movements have pushed the industry for timber harvesting and management, has begun to differentiate products through ecological processes. Moreover, the consumption for wood-based production has greatly affected due to the wood-based panel production to meet the demands from the building and furniture industries. Increased demand has influenced investors, consumers, regulatory agencies, and shareholders to develop their production strategies (Cinar et al., 2018). Not surprisingly, these attempts affect the furniture industry regarding the furniture and wood-based panel productions.

Varnishes and coatings have been used for furniture and wood protection in wider aspects since very ancient times. The use of resin based-based varnishes can be historically traced back to the ancient time such as Egyptian, Persian, Chinese, Greek or Indian culture (Cortina \& Carbo, 2004). In the industry, varnishes are classified by ASTM (2019) into four types. These are oil-based (film primarily chemical reaction), bituminous, spirit and spar varnishes. Varnishes are also classified for the polarity as oil or water-based varnishes (Wu et al., 2015; Cheng et al., 2018) and is the highest for ozone formation (Li et al., 2018).

A number of studies on the emissions concerned with varnishes for indoor air pollution (WHO, 1989; Clausen et al., 1991; Howard et al., 1998; McCrillis et al., 1999) shows that cyclic hydrocarbons, saturated aliphatic, oxygenated hydrocarbon and aromatic hydrocarbon have been identified both spirit varnishes and oil-based varnishes (Silva et al., 1998). The major VOCs for oil-based varnishes were identified as ethylbenzene, isobutanol, o-xylene, formaldehyde and m,p-xylene (Howard et al., 1998; Guo et al., 2002; Shun-Cheng et al., 2003).

The literature provides useful information concerned with the facts for the varnish selection when coating wood products and furniture. Experience for the ecological impression for furniture and wood products is a crucial agent for manufactures to develop the production strategies from ecologically approaches for "green" products. In the light of the above information, the hypotheses of this study are given below.

H1: There are significant differences between measurements of VOCs emission values on particleboard (PB) and medium density fiberboard (MDF) wood-based boards covered with varnish.

H2: There are significant differences for the values of VOCs emission in the wood-based panels concerning three different varnish types.

H3: There are differences between the measurement values of VOCs emissions in the wood-based boards at four different times. 


\section{MATERIAL AND METHOD}

\subsection{Wood Based Panels}

Standard particle panels (PB) with $18 \mathrm{~mm}$ thicknesses, manufactured in accordance with TS EN 312 (TSE, 2012) and MDF with 18 mm thicknesses, manufactured in accordance with TS EN 622-5 (TSE, 2011) were analyzed. The samples were veneered by beech with a thickness of $1,0 \mathrm{~mm}$ and varnished with three types of varnishes; respectively, cellulosic varnish, synthetic varnish and polyurethane varnish. These two types of wood-based panels and three types of varnishes are being commonly used in the furniture industry. The samples for the experiments were supplied from boards of 210x $280 \times 0.18 \mathrm{~cm}$ in accordance with TS EN 3261 (TSE, 1999).

\subsection{Preparation of Samples}

Twenty specimens were prepared from PB and MDF with $18 \mathrm{~mm}$ thicknesses. They were dimensioned by cutting into 500 x $500 \mathrm{~mm}$, weighed out with Precia Gravimetrics 312_6200C, in accordance with TS EN 326-1 (TSE, 1999), and each sample was numbered from 1 to 20, varnished with cellulosic, synthetic and polyurethane varnishes respectively. After drying, they were covered with nylon for avoiding emissions (Figure 1), and left at the temperature of $20^{\circ} \mathrm{C}$ and $60 / 65$ percent relative humidity in order to obtain a moisture value equal to the internal environmental conditions according to TS EN 2471 (TSE, 1976).
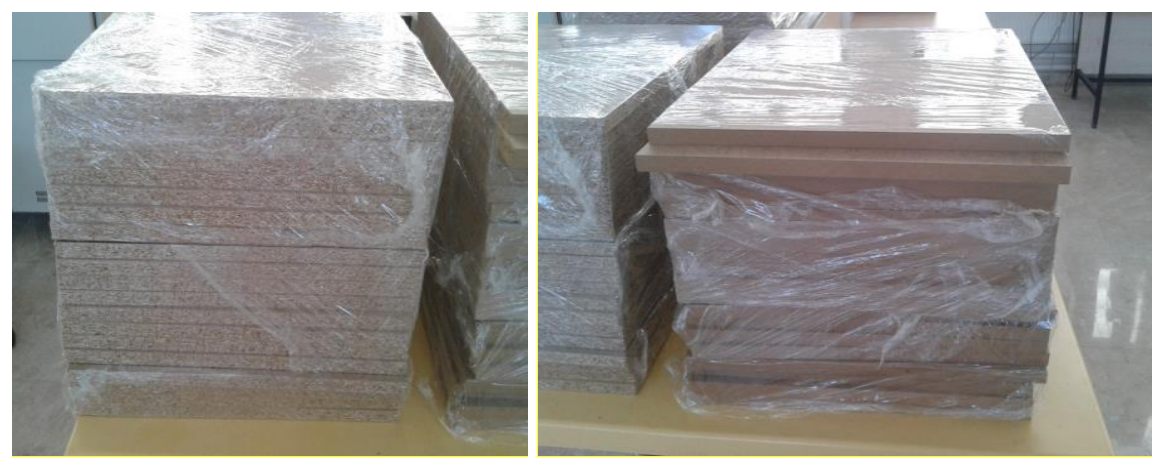

Figure 1. Number of Samples at Positions and Keeping Samples for Experiment

\subsection{Experiment Implementation}

Gas emissions were measured from newly veneered and edge covered PB and MDF, were left in store less than three days. Specimens were put into the Climatic Test Cabinet TK600NUVE (2012) at $20^{\circ} \mathrm{C}$ and $65 \%$ relative humidity for the $1^{\text {st }}$ measurements, which were taken by a multi- RAE multiple gas analyzer at 1,2 , and 3 hours over the test specimen prepared from boards supplied immediately from the factory in accordance with TS EN 13986 (TSE, 2015) and test method TS EN 717-1 (TSE, 2006). The measurements of TK600NUVE cabinet were 75 by 75 by $132 \mathrm{~cm}$, and a multi-RAE multiple gas analyzers were installed to the cabinet (Figure 2 and 3).

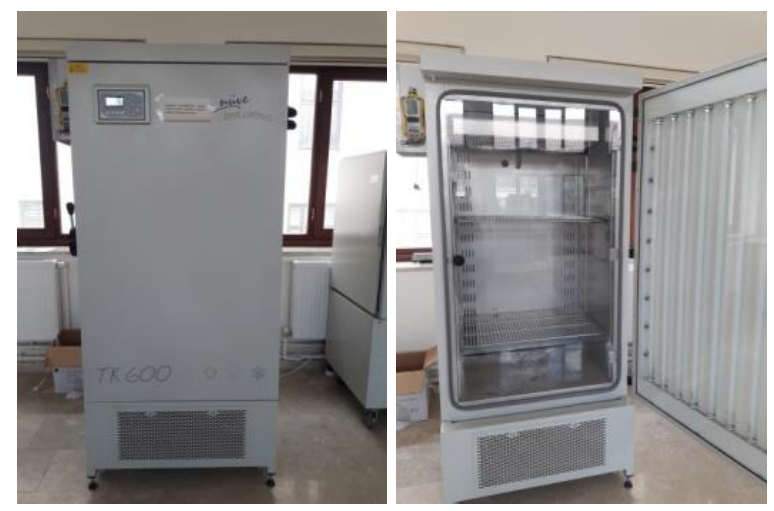

Figure 2. Climatic Test Cabinet 


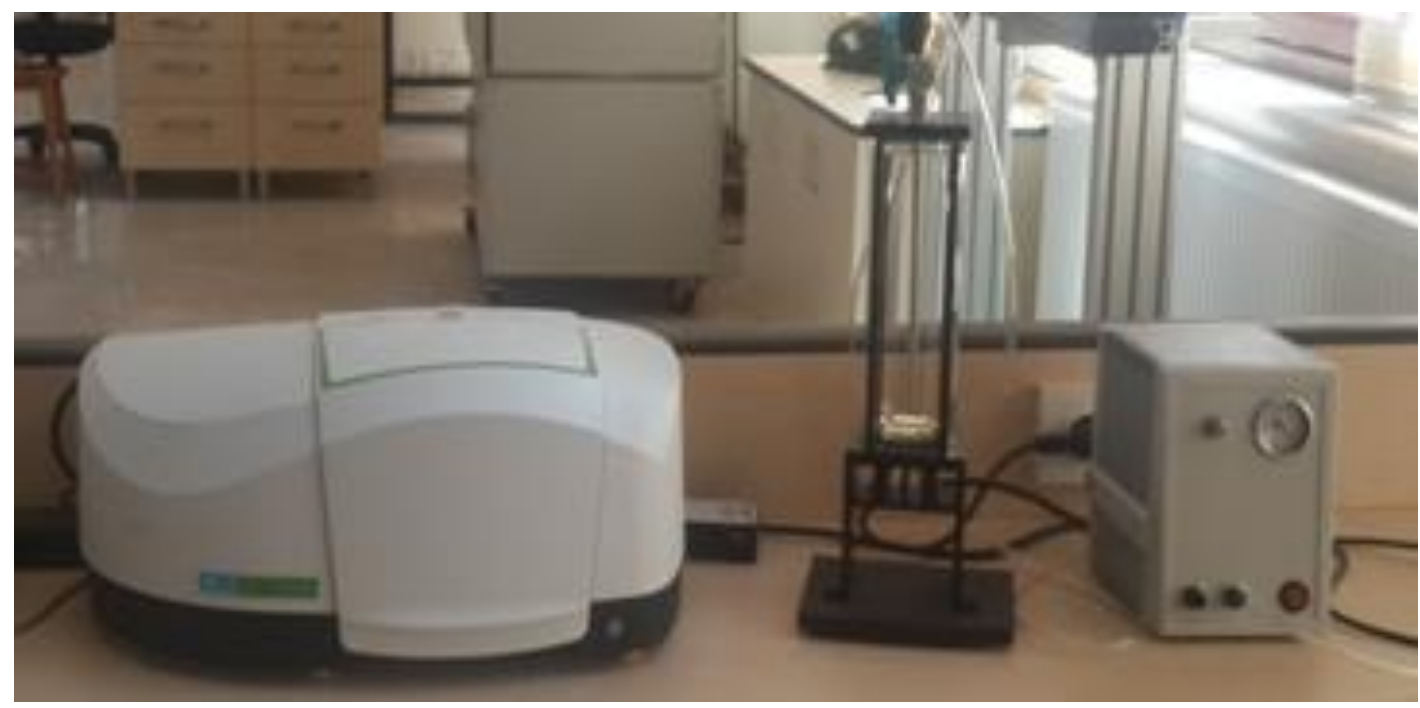

Figure 3. FTIR Spectrum Two ${ }^{\mathrm{TM}}$ Gas Analyzer

This study determined the effects of varnishes on nButylacetate, Toluene, Acetone, Isopropanol, Isobutylacetate and Paraxylene emissions for cellulosic, synthetic and polyurethane varnishes were determined and synthesized with the accepted limit values as ppm (per million particular part). Eco-Indicator 99 (Goedkoop \& Spriensma, 2000) was used to check the quantitative data representing VOC emission, which was measured according to TS EN 717-1 (TSE, 2006) by a FTIR SpectrumTwo TM Gas analyser.

\subsection{Statistical Analysis}

In order to carry out the effects of VOCs emission on varnished wood-based panels, data obtained from the measurements were summarized for understanding and comparing with the eco indicator results. Measurements of the VOCs emission in two different types of varnished wood-based boards (PB and MDF) were accepted as "dependent variables", whereas, the measurement time with wood-based board type and the varnish type were accepted as "independent variables." Afterwards, multivariate analysis of variance (MANOVA) was used to measure the effects of interactions between independent variables (board type X varnish type $\mathrm{X}$ time) depending on the measurement values of VOCs emission for the dependent variables. In addition, one-way analysis of variance (ANOVA) was used to examine the effect of differences in board type, varnish type, and measurement time (production moment, after drying, on the 15th day and 30th day) on VOCs emission in wood-based boards. The mean values found to be important in the analysis of variance are presented in graphic form.

\section{RESULTS}

Cronbach's Alpha test was used for reliability of dependent variables, and evaluations of values for VOCs emissions for examining. A coefficient of internal consistency of the Cronbach for two scales based on the VOC emissions measurement values are as follows: Particleboard (PB): 0.66; and Medium Density Fiberboard (MDF): 0.67. The reliability of the scale, which covers the measurement values of all dependent variables, is 0.67. Studies of Cronbach (1951) and Panayides (2013) state that the alpha reliability coefficients for all dependent variables could be accepted as 'reliable' while it is above 0.60 . This scale is reliable.

According to data obtained from the study, the differences among each independent variable evaluated and VOCs emission values variance analyzes were carried out and performed to determine the differences between board type * VOCs emission values, varnish type * VOCs emission values and time * VOCs emission values.

First, the effects of interactions for independent variables (board type $\mathrm{X}$ varnish type $\mathrm{X}$ time) depending on the measurement values of the VOC emission for dependent variables (nButylacetate, Toluene, Acetone, 
Isopropanol, Isobutylacetate and Paraxylene) were tested by using the multivariate analysis of variance (MANOVA) and given in Table 1.

Table 1. MANOVA, Independent Variables

\begin{tabular}{lccc}
\hline Independent Variables & F & df & Sig. \\
\hline Board type & 1.305 & 6 & $0.0263^{\text {ns }}$ \\
\hline Varnish type & 37.314 & 12 & $0.000^{*}$ \\
\hline Time & 7.424 & 18 & $0.000^{*}$ \\
\hline Board type*Varnish type & 0.823 & 12 & $0.627^{\text {ns }}$ \\
\hline Board type*Time & 0.703 & 18 & $0.808^{\text {ns }}$ \\
\hline Varnish type*Time & 7.091 & 36 & $0.000^{*}$ \\
\hline Board type*Varnish type*Time & 0.808 & 36 & $0.782^{\text {ns }}$ \\
\hline
\end{tabular}

Note: $* \alpha: 0.001$ is the level of significance, ${ }^{\text {ns: }}$ Not significant.

According to Table 1, the main effects (varnish type and time) and the two-way interaction for varnish type*time were found to be significant at a level of $p<0.001$. However, the main effect of board type, board type*varnish type and board type*time two-way interactions with board type*varnish type*time triple interaction were insignificant (at a level of $p<0.05$ ). Accordingly, binary and triple comparisons of board type do not influence VOCs emission measurement values. In other words, changing any varnish type or time factor in any board type did not significantly affect the total VOCs emission measurement value.

In another analysis, the ANOVA test results for the categorical averages, values of standard deviation and data obtained for differences for the measurement values of the VOCs emissions in the wood-based panels coated with varnish (PB and MDF) are given in Table 2.

Table 2. The ANOVA, Average Values, Standard Deviation and the Dependent Variables Related to the VOCs Emissions According to Wood-Based Panels

\begin{tabular}{|c|c|c|c|c|c|c|c|}
\hline \multirow{3}{*}{$\begin{array}{l}\text { Dependent } \\
\text { Variables }\end{array}$} & \multicolumn{4}{|c|}{ Wood-Based Boards } & \multirow{2}{*}{\multicolumn{3}{|c|}{ ANOVA Results }} \\
\hline & \multicolumn{2}{|c|}{ Particleboard (PB) } & \multicolumn{2}{|c|}{ Fiberboard (MDF) } & & & \\
\hline & M & $\mathrm{SD}$ & M & $\mathrm{SD}$ & $\mathrm{F}$ & df & Sig. \\
\hline nButylacetate & 35,696 & 66,452 & 35,609 & 72,045 & 0,000 & 1 & $0,995^{\mathrm{ns}}$ \\
\hline Toluene & 94,051 & 182,463 & 85,537 & 180,128 & 0,066 & 1 & $0,797^{\mathrm{ns}}$ \\
\hline Acetone & 10,734 & 50,268 & 11,157 & 38,463 & 0,003 & 1 & $0,959^{\text {ns }}$ \\
\hline Isopropanol & 2,655 & 27,719 & 2,443 & 32,549 & 0,001 & 1 & $0,970^{\mathrm{ns}}$ \\
\hline Isobutylacetate & 5,948 & 11,625 & 5,539 & 11,514 & 0,038 & 1 & $0,846^{\mathrm{ns}}$ \\
\hline Paraxylene & 2,173 & 3,094 & 1,776 & 2,704 & 0,555 & 1 & $0,458^{\mathrm{ns}}$ \\
\hline
\end{tabular}

Notes: ns: The differences among the groups are not significant at the level of $p<0.05$. M: Average value, SD: Standard deviation, F: F value, df: Degree of freedom.

According to Table 2, the differences for the dependent variables including the measurement values of the VOCs emissions in the panels were not found statistically significant (at a level of $p<0.05$ ) in terms of all the dependent variables related to the scale. These results show that the board type has no effect on the 
VOCs emission values measured from both wood-based boards covered with varnish. Figure 4 shows the graphical results.

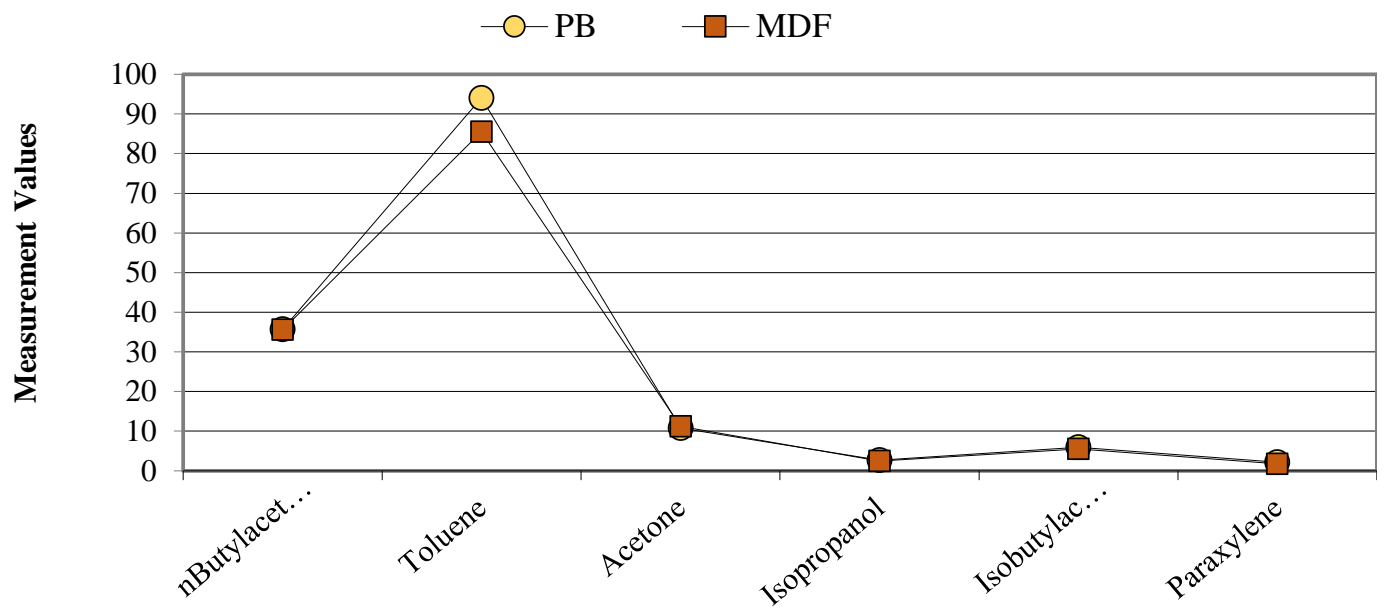

Figure 4. Effect of the Wood-Based Board Types on the VOC Emissions

According to Figure 4, the average measurement values of the VOC emissions in the boards covered with varnish are very close to each other for all the dependent variables related to the scale. There is no difference between the VOC emission measurements of both boards. This result shows that the H1 hypothesis, "There are significant differences between measurements of VOCs emission values on particleboard (PB) and medium density fiberboard (MDF) wood-based boards covered with varnish" was not supported.

The ANOVA test results for the data obtained for the differences between the measurement values of the VOCs emissions in boards using three different varnish types (cellulosic, synthetic and polyurethane varnish) are given in Table 3.

Table 3. ANOVA Test Results of the Dependent Variables Related to the VOCs Emissions According to Varnish Type

\begin{tabular}{|c|c|c|c|c|c|c|c|c|c|}
\hline \multirow{3}{*}{$\begin{array}{l}\text { Dependent } \\
\text { Variables }\end{array}$} & \multicolumn{6}{|c|}{ Varnish Type } & \multirow{2}{*}{\multicolumn{3}{|c|}{ ANOVA Results }} \\
\hline & \multicolumn{2}{|c|}{$\begin{array}{l}\text { Cellulosic } \\
\text { Varnish }\end{array}$} & \multicolumn{2}{|c|}{$\begin{array}{l}\text { Synthetic } \\
\text { Varnish }\end{array}$} & \multicolumn{2}{|c|}{$\begin{array}{c}\text { Polyurethane } \\
\text { Varnish }\end{array}$} & & & \\
\hline & M & $\mathrm{SD}$ & M & SD & M & $\mathrm{SD}$ & F & $\mathrm{df}$ & Sig. \\
\hline nButylacetate & 31,093 & 43,321 & 4,369 & 9,039 & 71,495 & 101,151 & 11,243 & 2 & $0,000^{*}$ \\
\hline Toluene & 191,977 & 267,658 & 12,582 & 15,068 & 64,822 & 100,876 & 12,452 & 2 & $0,000^{*}$ \\
\hline Acetone & 38,469 & 66,045 & $-0,344$ & 1,453 & $-5,287$ & 22,780 & 14,112 & 2 & $0,000 *$ \\
\hline Isopropanol & 21,337 & 42,206 & $-2,065$ & 3,823 & $-11,624$ & 19,477 & 15,864 & 2 & $0,000^{*}$ \\
\hline Isobutylacetate & 10,503 & 15,599 & $-0,074$ & 1,323 & 6,802 & 10,046 & 9,991 & 2 & $0,000^{*}$ \\
\hline Paraxylene & 0,688 & 0,492 & 1,700 & 1,616 & 3,507 & 4,299 & 11,250 & 2 & $0,000^{*}$ \\
\hline
\end{tabular}

Notes: *: The differences among the groups are significant at the level of $\mathrm{p}<0.001$.

M: Average value, SD: Standard deviation, F: F value, df: Degree of freedom.

According to Table 3, the differences for the dependent variables including the measurement values of the VOCs emissions in the boards using three different varnish types were found to be statistically significant at a level of $p<0.001$ in terms of all the dependent variables related to the scale. These results show that the 
varnish type has effect on the VOCs emission values measured from both boards covered with varnish. The result is given Figure 5.

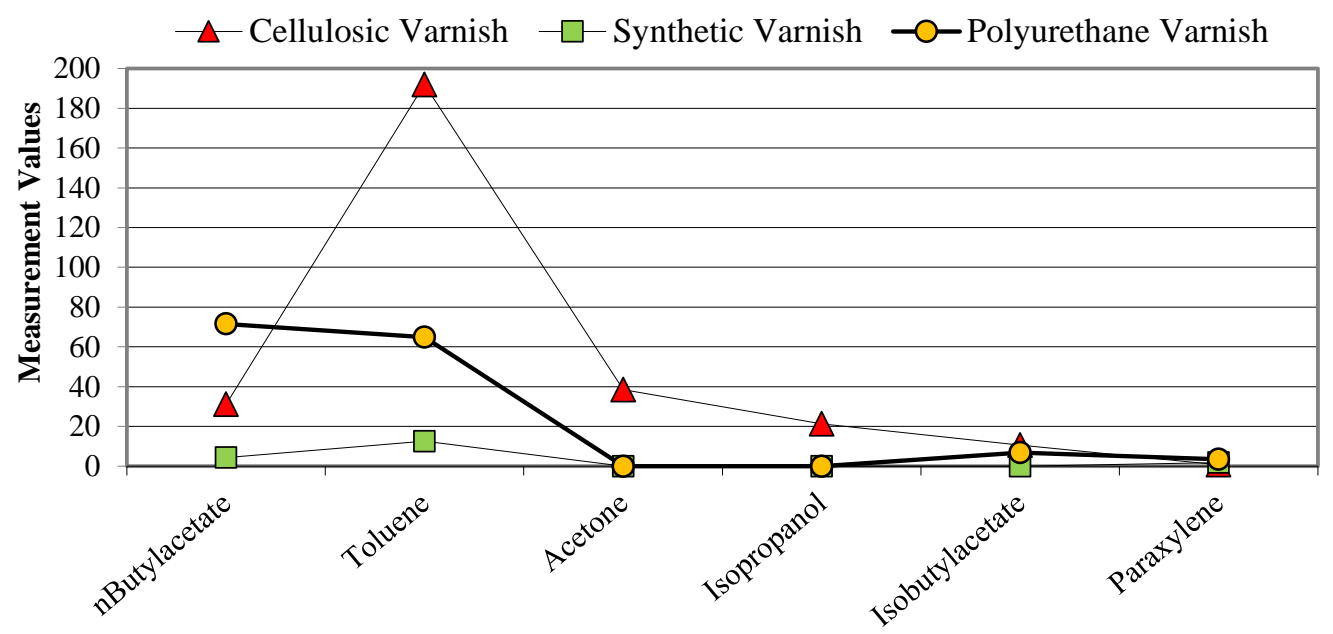

Figure 5. Effect of the Varnish Types on the VOC Emissions

According to Figure 5, the average measurement values of the VOCs emissions in the boards using three different varnish types were found to be quite different for all the dependent variables related to the scale. The figure shows that there are significant differences for the average measurement values of VOCs emissions in the boards using three different varnish types. This result supports the $\mathrm{H} 2$ hypothesis, which asserts "There are significant differences between for the values of VOCs emission from wood-based panels using three different varnish types". According to these results, it can be said that the board using cellulosic varnish gives more toluene gas release compared to the panels using other varnishes.

Table 4 gives ANOVA test results of the differences for the measurement values of VOC emissions in the panels at four different times (production moment, after drying, on the 15th day and 30th day).

Table 4. The Average, Standard Deviation and ANOVA Test Results of the Dependent Variables Related to the VOC Emissions According to Measurement Time

\begin{tabular}{|c|c|c|c|c|c|c|c|c|c|c|c|}
\hline \multirow{3}{*}{$\begin{array}{l}\text { Dependent } \\
\text { Variables }\end{array}$} & \multicolumn{8}{|c|}{ Measurement Time } & \multirow{2}{*}{\multicolumn{3}{|c|}{ ANOVA Results }} \\
\hline & \multicolumn{2}{|c|}{$\begin{array}{c}\text { Production } \\
\text { Moment }\end{array}$} & \multicolumn{2}{|c|}{ After Drying } & \multicolumn{2}{|c|}{ 15th Day } & \multicolumn{2}{|c|}{ 30th Day } & & & \\
\hline & M & SD & M & SD & M & SD & M & $\mathrm{SD}$ & $\mathrm{F}$ & $\mathrm{df}$ & $\mathrm{P}$ \\
\hline nButylacetate & 106,469 & 106,242 & 28,690 & 28,009 & 6,144 & 10,107 & 1,307 & 3,274 & 23,354 & 3 & $0,000 *$ \\
\hline Toluene & 282,877 & 268,754 & 68,928 & 84,522 & 6,126 & 8,561 & 1,243 & 1,744 & 26,461 & 3 & $0,000^{*}$ \\
\hline Acetone & 38,395 & 83,075 & 6,947 & 12,903 & $-0,901$ & 1,475 & $-0,658$ & 0,629 & 5,909 & 3 & $0,001^{*}$ \\
\hline Isopropanol & 14,847 & 57,456 & $-3,117$ & 13,435 & $-1,646$ & 4,376 & $-0,112$ & 1,956 & 2,361 & 3 & $0,075^{*}$ \\
\hline Isobutylacetate & 18,309 & 16,367 & 5,036 & 5,998 & 0,035 & 1,849 & $-0,406$ & 0,928 & 29,704 & 3 & $0,000^{*}$ \\
\hline Paraxylene & 4,5819 & 4,530 & 1,981 & 1,512 & 0,799 & 0,749 & 0,492 & 0,489 & 17,313 & 3 & $0,000^{*}$ \\
\hline
\end{tabular}

Notes: *: The differences among the groups are significant at the levels of $p<0.10$ and $p<0.001$.

M: Average value, SD: Standard deviation, F: F value, df: Degree of freedom.

Table 4 gives ANOVA results for the differences for the dependent variables including the values for VOCs emissions in the panels at four different times, were found to be statistically significant at a level of $p<0.001$ in terms of all the dependent variables. These results show that the measurement time has effect on the VOCs 
emission values measured from both boards covered with varnish. Figure 6 gives the values after drying, $15^{\text {th }}$ day and $30^{\text {th }}$ day results.

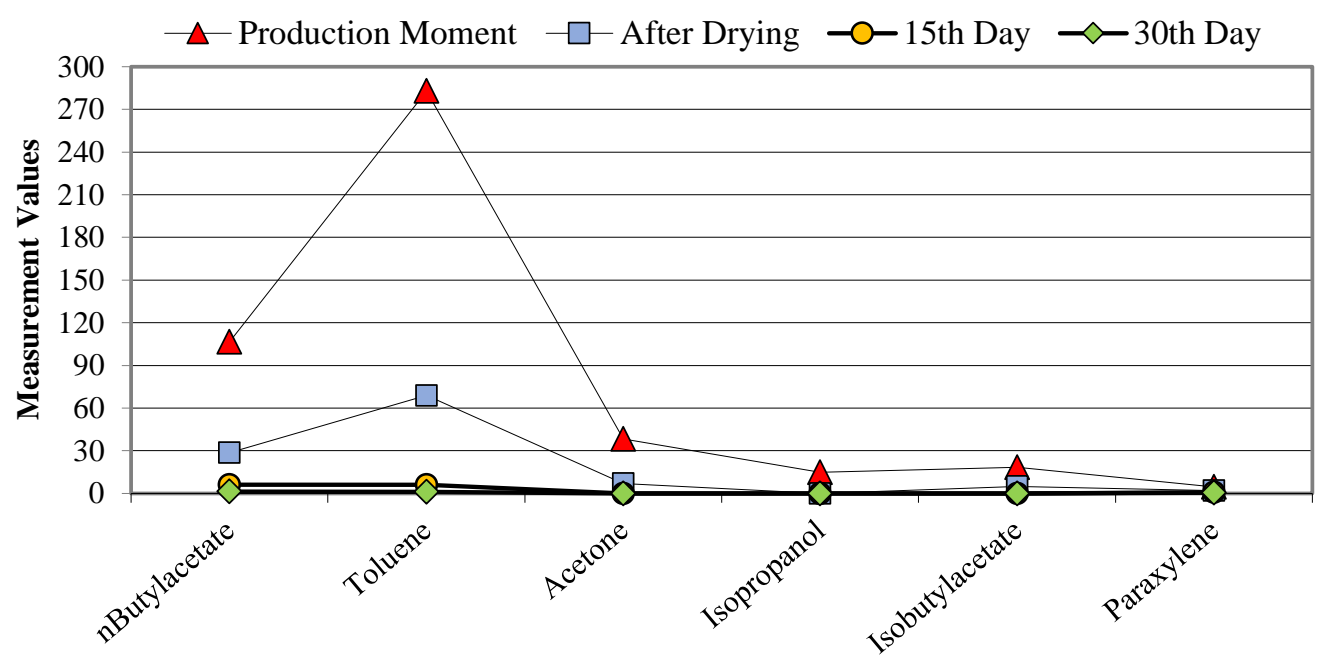

Figure 6. Effect of the Measurement Time on the VOCs Emissions

The average values of VOCs emissions in the boards using three different varnish types were found to be quite different for all the dependent variables related to the scale according to Figure 6 . The figure shows that there are significant differences for the average measurement values of VOCs emissions in the boards at four different times. The $\mathrm{H} 3$ hypothesis, is supported, asserts "There are differences between the measurement values of VOCs emissions in the wood-based boards at four different times". According to these results, it is seen that the VOCs emission value is reset on the 30th day in the measurements made on the boards.

\section{CONCLUSION}

This paper analyzed the effects of varnishes on nButylacetate, Toluene, Acetone, Isopropanol, Isobutylacetate and Paraxylene emissions for cellulosic, synthetic and polyurethane varnishes for VOCs. The following conclusion can be made:

$\checkmark$ The highest value was 624,90 ppm for Toluene, while the lowest was 0,30 ppm for Para xylene in respect to the Particleboards which were covered by beech veneered and varnished with cellulosic varnish. However, samples of beech veneered and varnished with synthetic and polyurethane varnishes yielded less gas emission than cellulosic varnish.

$\checkmark$ The samples of MDF, covered with beech veneer and varnished polyurethane varnished yielded gas emission more than the synthetic (100\%) and cellulosic varnishes $(220 \%)$.

$\checkmark$ In accordance with the results, it can be said that cellulosic, synthetic and polyurethane varnishes, which are widely used in the sector in terms of protection and visual appearance, are not considered as environmentally friendly.

Considering manufacturing furniture, raw materials and semi-finished materials in line with the product life cycle, selection and application of varnishes used for protection are significantly important in terms of environmentally friendly products. All values show that gas emission reduces its effect within time in respect to the manufacturing time, after drying period, 15- and 30-days measurements. After the application of varnishes, it is important to make ventilation frequently daily and to ensure air circulation in closed environments.

Giving a thought into the number of products, components, elements and agents in the furniture industry and interiors for design projects, it is possible to say that there is a high responsibility for designers in order to be aware of the consequence of their work for ecological aspects for the eco-friendly and sustainable production and are supposed to start taking into account eco design issues concerned with the impacts on the environment. 


\section{CONFLICT OF INTEREST}

The authors declare no conflict of interest.

\section{REFERENCES}

Akkuş, M., Akbulut, T., \& Candan, Z. (2021). Formaldehyde emission, combustion behavior, and artificial weathering characteristics of electrostatic powder coated wood composite panels. Wood Material Science \& Engineering. doi:10.1080/17480272.2021.1901142

Andersson, K., Bakke, J. V., Bjørseth, O., Bornehag, C-G., Clausen, G., Hongslo, J. K., Kjellman, M., Kjærgaard, S., Levy, F., Mølhave, L., Skerfving, S., \& Sundell, J. (1997). TVOC and health in non-industrial indoor environments. INDOOR AIR International Journal of Indoor Air Quality and Climate, 7(2), 78-91. doi:10.1111/j.1600-0668.1997.t01-2-00002.x

ASTM, American Society for Testing and Materials. (2019). Standard Specification for Standard Environment for Conditioning and Testing Paint, Varnish, Lacquer, and Related Materials (D3924-16, Active Standart), Philadelphia, PA. (Accessed:19/1 1/2021) https://www.astm.org/Standards/D3924.htm

Bartzis, J., Wolkoff, P., Stranger, M., Efthimiou, G., Tolis, E. I., Maes, F., Nørgaard, A. W., Ventura, G., Kalimeri, K. K., Goelen, E., \& Fernandes, O. (2015). On organic emissions testing from indoor consumer products' use. Journal of Hazardous Materials, 285, 37-45. doi:10.1016/j.jhazmat.2014.11.024

Benotto, E., Becker, M., \& Welfring, J. (2009). Life cycle assessment of oriented strand boards (OSB): From process innovation to eco-design. Environmental Science Technology Journal, 43(15), 6003-6009. doi: $10.1021 /$ es $900707 \mathrm{u}$

Brockmann, C. M., Sheldon, L. S., Whitaker., D. A., \& Baskir, J. N. (1998). The Application of Pollution Prevention Techniques to Reduce Indoor Air Emissions from Engineered Wood Products (Report No. EPA600/R-98-146), U.S. Environmental Protection Agency, Washington, DC.

Bulian, F., \& Fragassa, C. (2016). VOC emissions from wood products and furniture: A survey about legislation, standards and measures referred to different materials. FME Transactions, 44(4), 358-364. doi:10.5937/fmet1604358B

Cacho, C., Ventura Silva, G., Martins, A. O., Fernandes, E. O., Saraga, D. E., Dimitroulopoulou, C., Bartzis, J. G., Rembges, D., Barrero-Moreno, J., \& Kotzias, D. (2013). Air pollutants in office environments and emissions from electronic equipment: A review. Fresenius Environmental Bulletin, 22(9), 2488-2497.

Cheng, K., Hao, W-W., Yi, P., Zhang, Y., \& Zhang, J-Y. (2018). Volatile organic compounds emission from chinese wood furniture coating industry: Activity-based Emission factor, speciation profiles, and provincial emission inventory. Aerosol and Air Quality Research, 18(11), 2813-2825. doi:10.4209/aaqr.2018.02.0044

Cinar, H. (2005). Eco design and furniture: Environmental impacts of wood-based panels, surface and edge finishes. Forest Products Journal, 55(11), 27-33.

Cinar, H. (2018). Effects of temperature and thickness of wood-based boards on formaldehyde emission. Wood Research, 63(5), 895-908.

Cinar, H., \& Erdogdu, M. (2018). Eco-Design: Effects of thickness and time in service for wood-based boards on formaldehyde emission. Forest Products Journal, 68(4), 405-413. doi:10.13073/FPJ-D-17-00027

Cinar, H., Ozturk, Y., \& Yıldırım, K. (2018). Effects of surface veneering, edge banding, drilling holes for handles and hinges of wood-based boards on formaldehyde emission. Forest Products Journal, 68(3), 264271.

Clausen, P. A., Wolkoff, P., Host, E., \& Nielsen, P. A. (1991). Long-term emission of volatile organic compounds from waterborne paints. INDOOR AIR International Journal of Indoor Air Quality and Climate, 1(4), 562-576. doi:10.1111/j.1600-0668.1991.00019.x

Climatic Test Cabinet (2012). NÜVE Industrial Materials for production and Trade IC. Model TK 600 (W). Volume 600 Lt. Max. Temp. $-10 / 60^{\circ} \mathrm{C}$. Ankara, Turkey. 
Cronbach, L. J. (1951). Coefficient alpha and the internal structure of tests. Psychometrika, 16(3), 297-334. doi: $10.1007 / \mathrm{BF} 02310555$

Fechter, J-O., Englund, F., \& Lundin, A. (2006) Association between temperature, relative humidity and concentration of volatile organic compounds from wooden furniture in a model room. Wood Material Science \& Engineering, 1(2), 69-75. doi:10.1080/17480270600900551

Goedkoop, M., \& Spriensma, R. (2000). The Eco-Indicator 99: A Damage Oriented Method for Life Cycle Impact Assessment (Methodology Report, nr.1999/36A), Product Ecology Consultants B. V., Amersfoort, Netherlands.

Guo, H., Lee, S. C., \& Kwok, N-H. (2002). Modeling of VOCS emissions from a varnish. Proceedings: Indoor Air, 226-231. (Accessed:19/11/2021) https://www.irbnet.de/daten/iconda/CIB7084.pdf

Hidayetoglu, M. L., \& Muezzinoglu, K. M. (2018). User-involved universal design experience in the space, product and service development process. ICONARP International Journal of Architecture and Planning, 6 , 41-62. doi:10.15320/ICONARP.2018.48

Howard, E. M., McCrillis, R. C., Krebs, K. A., Fortmann, R., Lao, H. C., \& Guo, Z. (1998). Indoor emissions from conversion varnishes. Journal of Air \& Waste Management Association, 48(10), 924-930.

Kephalopoulos, S., Crump, D., Däumling, C., Funch, L. W., Horn, W., Keirsbulck, M., Maupetit, F., Sateri, J., Saarela, K., Scutaru, A. M., Tirkkonen, T., Witterseh, T., \& Sperk, C. (2012). Harmonisation framework for indoor products labelling schemes in the EU (European Collaborative Action Report no. 27). European Commission Joint Research Centre. Publications Office of the European Union, Luxembourg. doi: $10.2788 / 20292$

Li, G., Wei, W., Shao, X., Nie, L., Wang, H., Yan, X., \& Zhang, R. (2018). A comprehensive classification method for VOC emission sources to tackle air pollution based on VOC species reactivity and emission amounts. Journal of Environmental Sciences, 67, 78-88. doi:10.1016/j.jes.2017.08.003

McCrillis, R. C., Howard, E. M., Guo, Z., Krebs, K. A., Fortmann, R., \& Lao, H. C. (1999). Characterization of curing emissions from conversion varnishes. Journal of Air \& Waste Management Association, 49(1), 7075.

Missia, D. A., Demetriou, E., Michael, N., Tolis, E. I., \& Bartzis, J. G. (2010). Indoor exposure from building materials: A field study. Atmospheric Environment, 44(35), 4388-4395. doi:10.1016/j.atmosenv.2010.07.049

Nandan, A., Siddiqui, N. A. \& Kumar, P. (2020). Estimation of indoor air pollutant during photocopy/printing operation: A computational fluid dynamics (CFD)-based study. Environmental Geochemistry and Health, 42, 3543-3573. doi:10.1007/s10653-020-00589-0

Panayides, P. (2013). Coefficient Alpha: Interpret with caution. Europe's Journal of Psychology, 9(4), 687696. doi:10.5964/ejop.v9i4.653

Subaşı, T., Çınar, H., \& Çağatay, K. (2017). Mobilya sektöründe kullanılan kompozit malzemelerin insan yaşamına ve çevreye etkileri. Illeri Teknoloji Bilimleri Dergisi, 6(3), 557-571.

TSE, Turkish Standards Institution (1976). Wood, Determination of Moisture Content for Physical and Mechanical Tests (TS 2471, Active Standart), Ankara.

TSE, Turkish Standards Institution (1999). Wood- Based panels- Sampling, cutting and inspection- Part 1: Sampling test pieces and expression of test results (TS EN 326-1, Active Standart), Ankara.

TSE, Turkish Standards Institution (2006). Wood - based panels - Determination of formaldehyde release Part 1: Formaldehyde emission by the chamber method (TS EN 717-1, Active Standart), Ankara, Turkey.

TSE, Turkish Standards Institution (2011). Fibreboards - Specifications - Part 5: Requirements for dry process boards (MDF) (TS EN 622-5, Active Standart), Ankara.

TSE, Turkish Standards Institution (2012). Particleboards- Specification (TS EN 312, Active Standart), Ankara. 
TSE, Turkish Standards Institution (2015). Wood-based panels for use in construction - Characteristics, evaluation of conformity and marking (TS EN 13986:2004+A1, Active Standart), Ankara.

Ulker, O. C., Ulker, O., \& Hiziroglu, S. (2021). Volatile organic compounds (VOCs) emitted from coated furniture units. Coatings, 11(7), 806. doi:10.3390/coatings11070806

WHO, World Health Organization (1989). Indoor Air Quality: Organic Pollutants, WHO Regional Office for Europe, EURO Reports and Studies No. 111, Copenhagen.

Wu, X., Huang, W., Zhang, Y., Zheng, C., Jiang, X., Gao, X., \& Cen, K. (2015). Characteristics and uncertainty of industrial VOCs emissions in China. Aerosol and Air Quality Research, 15(3), 1045-1058. doi:10.4209/aaqr.2014.10.0236

Yıldırım, K., Müezzinoğlu, M. K., \& Bozkurt, O. (2020). Konutlarda Döşemeli Mobilyaların Değiştirilme Süreçlerinin İncelenmesi. Selçuk-Teknik Dergisi, 19(2), 68-83.

Yıldırım, K., Müezzinoğlu, M. K., \& Türkdal, S. (2021). Fiziksel Engelli Kullanıcıların İç Mekân Donatı Elemanlarına Yönelik Tercihlerinin Belirlenmesi. Uluslararası Disiplinlerarası ve Kültürlerarası Sanat, 6(12), 193-213.

Yu, C. W. F., \& Kim, J. T. (2012). Long-term impact of formaldehyde and VOC emissions from wood-based products on indoor environments; and issues with recycled products. Indoor and Built Environment, 21(1), 137-149. doi: $\underline{10.1177 / 1420326 X 11424330}$ 